\title{
“Satan Made Me Do It!” The Development of a Satan Figure as Social-Theological Diagnostic Strategy from the late Persian Imperial Era to Early Christianity
}

\author{
LOUIS C. JONKER (UNIVERSITY OF STELLENBOSCH)
}

\begin{abstract}
\end{abstract}
The purpose of this article is, first of all, to provide a short overview of the socio-religious development to personalise evil into a Satan figure alongside God. Thereafter, I will provide one biblical example which stands at the beginning of this development, namely $1 \mathrm{Chr} 21$. This text analysis will merely serve as one example to illustrate the relationship between the socio-religious developments in the Second Temple period and biblical textual formation through the reinterpretation of earlier traditions. In a last section, I will reflect on how our awareness of this relationship between socio-religious development and reinterpretation affects how Christian theology participates in social-theological diagnostics today.

KEYWORDS: Satan; Persian dualism; Social-theological diagnostics; 1 Chronicles 21:1

\section{A INTRODUCTION}

In the first week of June 2000 the newspaper, The Guardian, reported the following: ${ }^{1}$

The beleaguered former captain of South Africa Hansie Cronje, at the centre of cricket's match-fixing scandal, has made another confession, this time to a church leader, in which he lays the blame for his misconduct firmly at Satan's door.

* Article submitted: 31/01/2017; peer-reviewed: 1/03/2017; accepted: 2/04/2017. Louis J. Jonker, “'Satan Made Me Do It!' The Development of a Satan Figure as Social-Theological Diagnostic Strategy from the late Persian Imperial Era to Early Christianity," Old Testament Essays 30 (2017): 348-366, doi: http:// dx.doi.org /10.17159/2312-3621/2017/v30n2a10

1 Adam Szreter, "Cronje names devil who made him do it," The Guardian, 2 June 2000 . 
The confession, made in Cronje's home country to the Rhema Church leader Ray McCauley, has made its way to the official commission of inquiry that was instituted after Indian police accused Cronje and other South African cricketers of having rigged matches during the recent tour of the sub-continent. The inquiry begins next week.

"In a moment of stupidity and weakness I allowed Satan and the world to dictate terms to me," Cronje says in the confession. "The moment I took my eyes off Jesus my whole world turned dark."

This statement by the late captain of the Protea cricket team shocked some, amused some others, and was seen by still others as a crystal clear explanation of what really happened: Satan made him do it! ${ }^{2}$

This is only one well-known case of blaming Satan for misconduct, although this practice is not uncommon in some religious circles in South Africa and wider. What is wrong in society, or what is wrong in personal conduct, is often explained in these religious contexts as the work of Satan. In my view (which is surely determined by my own cultural, religious and ideological background) this diagnostic strategy externalises guilt in order to escape societal or personal responsibility for wrongs done to others or for unethical and even illegal conduct.

This strategy of involving a personalised Satan in social-theological and personal diagnostics ${ }^{3}$ is not unique to our modern world and context.

2 The celebrant in this volume, prof Sakkie Spangenberg of UNISA, has written and published in various popular and academic fora on the topic of the "devil." See e.g. his historical overview article, Izak J. J. Spangenberg, "A Brief History of Belief in the Devil (950 BCE - 70 CE)," SHE 39 Supplement (2013): 213-45. Spangenberg was despised by some South African interlocutors, mainly from conservative Afrikaans extraction, for indicating that belief in the devil cannot be classified as a pure biblical belief. I honour him with this essay, not only for his courage to bring critical biblical scholarship on the belief in the devil into the public realm and into interaction with Christian theology, but also for a lifelong career in OT Studies. I also thank him for years of good cooperation on the OTSSA executive, and wish him well for the new phase in his career and life.

3 I borrow and adapt these terms from an on-going research project conducted by systematic theologian, prof. Ernst M. Conradie of the University of the Western Cape, as fellow of the Stellenbosch Institute of Advanced Study (STIAS). See a description of the research project at Ernst M. Conradie, "The Malaise of the Human Condition: Social Diagnostics, Human Evolution, and Theological Discourse on the Contingency of Sin," STIAS: Stellenbosch Institute for Advanced Study. http://stias.ac.za/research/projects/the-malaise-of-the-human-condition-socialdiagnostics-human-evolution-and-theological-discourse-on-the-contingency-of-sin/. 
Already in the intertestamental period and in the NT Satan is considered to exist. Not only do the Gospels tell of Jesus's personal conversations with Satan who puts different tests before him, but illnesses and inexplicable behaviour are also attributed to Satan, or related to evil spirits. Late Second Temple Judaism and the NT writings therefore witness to a religious context within which a Satan figure, or the personalisation of evil, was already wellestablished. ${ }^{4}$

This was not always the case, however. Satan was a late-comer in the religious developments from monotheistic Yahwism of OT times to the early Christian understanding as witnessed in the NT writings that originated during the Roman era. Scholars are in agreement that the dualistic worldview that started developing in the late Achaemenid era played a major role in the personalisation of evil into a Satan figure that happened in the pre-Christian era. $^{5}$

The purpose of my article is, first of all, to provide a short overview of the socio-religious development to personalise evil into a Satan figure along-

. He takes his cue from the Diagnostic Report of 2011 that was issued by the National Planning Commission of South Africa. However, part of this project is to investigate the plausibility of the assumption of the contingency of $\sin$ in Christian discourse. I therefore rather use the term "social-theological diagnostics" to latch onto this discussion of Conradie.

4 Chad T. Pierce, "Satan and Related Figures," ed. John J. Collins and Daniel C. Harlow, The Eerdmans Dictionary of Early Judaism (Grand Rapids: Eerdmans, 2010), 1199, indicates: "Satan as a proper name for God's evil enemy is used thirtyfive times in the New Testament. The New Testament writers often use a variety of other terms for God's celestial enemy, including 'Bellezebul' (beelzebul) or 'prince of demons' (Mark 3:22; Matt. 12:24-27; Luke 11:15-19); 'the evil one' (Matt. 5:37; 13:19, 38; John 17:15; Eph. 6:16; 2 Thess. 3:3; 1 John 2:13, 14); 'the tempter' (Matt. 4:3); 'the enemy' (Matt. 13:39); and 'ruler of this world' (John 16:11). In addition to Satan, the name for God's enemy most often used in the New Testament is 'the Devil' (ho diabolos, 32 times)." See also Elaine Pagels, The Origin of Satan: How Christians Demonized Jews, Pagans, and Heretics (London: Penguin Vintage, 2011); Jonathan Burke, "Satan and Demons in the Apostolic Fathers: A Minority Report," SEA 81 (2016): 127-68; Jan Dochhorn, Susanne Rudnig-Zelt, and Benjamin G. Wold, eds., Das Böse, der Teufel und Dämonen: Evil, the Devil, and Demons, WUNT 2/412 (Tübingen: Mohr Siebeck, 2016); Sebastian Fuhrmann, "The Devil as (Convicted) Prosecutor: Some Ideas on the Devil in 1 Peter and Hebrews," IDS 50/2 (2016): 1-4; Chris Keith and Loren T. Stuckenbruck, eds., Evil in Second Temple Judaism and Early Christianity, WUNT 2/417 (Tübingen: Mohr Siebeck, 2016); Derek R. Brown, The God of this Age: Satan in the Churches and Letters of the Apostle Paul (Tübingen: Mohr Siebeck, 2015); Ida Fröhlich and Erkki Koskenniemi, eds., Evil and the Devil (London: T \& T Clark, 2013).

5 See again Spangenberg, "Brief History." 
side God. Thereafter, I will provide one biblical example which stands at the beginning of this development, namely $1 \mathrm{Chr} 21$. This text analysis will merely serve as one example to illustrate the relationship between the socioreligious developments in the Second Temple period and biblical textual formation through the reinterpretation of earlier traditions. In a last section, I will reflect on how our awareness of this relationship between socio-religious development and reinterpretation impacts on how Christian theology participates in social-theological diagnostics today.

In my discussion I will depart from the presupposition that the externalisation of evil from God into a personal Satan figure is not only a clear strategy of social-theological diagnostics, but also witnesses to the dynamic relationship between social-religious developments, socialtheological diagnostics and the formation of doctrine. I will return to this presupposition in the final part of my paper in order to play the role of "devil's advocate" (pun intended).

\section{B A VERY SHORT HISTORY OF SATAN: SOCIO-RELIGIOUS DEVELOPMENTS FROM THE LATE ACHAEMENID ERA TO EARLY CHRISTIANITY}

The emergence of Persian imperial domination in the ANE from 539 BCE and the resulting return from exile by Judahites and Israelites had a decisive impact on Yahwistic theology in Jerusalem and its influence sphere. ${ }^{6}$ Not only did these developments introduce a totally new socio-political dispensation, but it also contributed significantly to the emergence of literary expressions of this theology which later became part of the HB (and eventually, the OT of Christianity). Although one should not over-estimate the so-called "tolerance" of the Persian imperial regime in terms of religious diversity, it seems from the HB that there was an overwhelming acceptance of Persian views and policies, and that there were even attempts to claim Cyrus the Great of Persia as some sort of "messiah" or "prophet" of Yahweh (see e.g. Isa 45:1; $2 \mathrm{Chr} 26: 22-23){ }^{7}$ There is therefore no doubt that religious conditions of the Persian imperial period also impacted on Yahwistic theology.

6 For a further discussion of the influence of Persian imperial domination, see Louis C. Jonker, Defining All-Israel in Chronicles: Multi-Levelled Identity Negotiation in Late Persian Period Yehud, FAT I/106 (Tübingen: Mohr Siebeck, 2016), 8995. See also Susanne Rudnig-Zelt, "Der Teufel und der alttestamentliche Monotheismus," in Das Böse, der Teufel und Dämonen: Evil, the Devil, and demons, ed. Jan Dochhorn, Susanne Rudnig-Zelt, and Benjamin G. Wold, WUNT 2/412 (Tübingen: Mohr Siebeck, 2016), 1-20.

7 This assumption is often instigated by the contents of the Cyrus Cylinder which was discovered in Babylon. However, Erich Gruen rightly points out that some other 
It is unsure whether the early Achaemenid kings, including Cyrus the Great, already worshiped Ahuramazda. ${ }^{8}$ Like some of the other Iranian ethnic groups they rather believed that the earth, sky, water, fire, rivers, and mountains, were sacred. However, by the time of Darius I the cult of Ahuramazda received royal acceptance and therefore rose to prominence. This is evident from numerous of Darius' royal inscriptions where he claims that he reigned "by the favour of Ahuramazda." It seems that from Artaxerxes II and onwards a further development took place, namely two additional deities, the sun-god Mithra and Anahita, the goddess of water and fertility, were elevated in the royal cult alongside Ahuramazda. ${ }^{9}$ Maria Brosius states:

The worship of a sun-god and a goddess of water comes as no surprise in a country where both elements are held in high regard, as they dominate agricultural life and determine the well-being of its people. ... The Persians' creation of extensive gardens was the epitome of their ability to defy nature and to create sources of water even in dry areas, allowing the cultivation of seemingly nonarable land. ${ }^{10}$

While Ahuramazda worship was prominently mentioned in the royal inscriptions and depicted in iconography, one would assume that the cult was also imposed on the subjugated peoples. However, this was not the case. Local autonomy was allowed to a great extent. For example, locals were appointed as governors and representatives of the central empire in the provincial and satrapal centres. But, these local citizens also had to represent the local context in the imperial centre. They were therefore often in a dichotomous situation. In Jerusalem, this would mean that the local officials would form part of the Yahwistic religious community, worshiping in the rebuilt

biblical passages do indeed critique the Persian Empire subtly. See Erich S. Gruen, "Persia through the Jewish Looking-Glass," in Jewish Perspectives on Hellenistic Rulers, ed. Tessa Rajak, et al., (Berkeley: University of California Press, 2007), 53-75.

8 Matt Waters indicates: "The Achamenids (sic) are often described as Zoroastrians. This is perhaps an apt characterization on the surface - especially if one focuses only on the ideology as expressed in the royal inscriptions - but one that does not do justice to the variety of evidence." See Matt W. Waters, Ancient Persia: A Concise History of the Achaemenid Empire, 550-330 BCE (Cambridge: Cambridge University Press, 2014), 151.

9 Maria Brosius, The Persians: An Introduction, PAW (London: Routledge, 2006), 66.

10 Brosius, Persians, 67. See also Louis C. Jonker, "Manasseh in Paradise, or Not? The Influence of ANE Palace Garden Imagery in LXX 2 Chronicles 33:20," in Thinking of Water in the Early Second Temple Period, ed. Christoph Levin and Ehud Ben Zvi, BZAW 461 (Berlin: De Gruyter, 2014), 339-58. 
temple of Jerusalem, but would also have had to illustrate their solidarity with the Empire by honouring Ahuramazda.

From the time of Xerxes it seems that religious conditions in the Persian Empire started hardening. Scholars mainly refer to the Daiva inscription (XPh), authored by Xerxes in $480 \mathrm{BCE},{ }^{11}$ to motivate the assumed change. The text mentions, for example, the following:

Proclaims Xerxes, the king: When I became king, there is among those countries which (are) inscribed above (one, which) was in turmoil. Afterwards Auramazdā brought me aid; by the favour of Auramazdā I defeated that country and put it in its proper place.

And among those countries there were (some), where formerly the Daivas have been worshipped. Afterwards by the favour of Auramazdā I destroyed that place of the Daivas, and I gave orders: "The Daivas shall not be worshipped any longer!" Wherever formerly the Daivas have been worshipped, there I worshipped Auramazdā at the proper time and in the proper ceremonial style $\left(\mathrm{XPh}\right.$, lines 28-41). ${ }^{12}$

What the key word in this section, daivas,${ }^{13}$ means is not so clear. Some scholars translate it with "demons." They thereby suggest that Xerxes viewed other deities as "demons," in contrast to the true god Ahuramazda. If this understanding is correct, this text would witness harshly to religious intolerance, and inversely, to the promotion of Ahuramazda as sole deity.

However, recently Amélie Kuhrt and others have started pointing out that this view is heavily influenced by the very negative portrayal of Xerxes as a king who destroyed foreign temples in Babylon, a view which was instigated by a careless reading of Herodotus. ${ }^{14}$ Scholars are therefore increa-

11 Rüdiger Schmitt says the following about this text: "This inscription, which is one of the most important texts by King Xerxes with regard to its content and message, is one of the most-discussed texts, too, chiefly in connection with its date and its implications for the historical geography and the religious history of Ancient Iran." See Rüdiger Schmitt, The Old Persian Inscriptions of Naqsh-I Rustam and Persepolis, Corpus Inscriptionum Iranicarum 1/2 (London: School of Oriental and African Studies, 2000), 93.

12 Translation of Schmitt, The Old Persian Inscriptions.

13 See Clarisse Herrenschmidt and Jean Kellens, "Daiva," EIr 6/6 (1993): 599-602, online: http://www.iranicaonline.org/articles/daiva-old-iranian-noun.

14 Amélie Kuhrt indicates that this negative portrayal of Xerxes "was based on a careless reading of Herodotus combined with incomplete Babylonian evidence and an implicit wish to make very disparate types of material harmonize with a presumed 'knowledge' of Xerxes' actions, policies, and character." See Amélie Kuhrt, "Reassessing the Reign of Xerxes in the Light of New Evidence," in 
singly associating this inscription with the rebellions that occurred in the early years of Xerxes' reign. Whereas Cyrus the Great was the initiator of the Empire, and Darius I the builder, Xerxes had to stabilise the Empire after rebellions in Egypt and Babylonia. ${ }^{15}$ Xerxes' Daiva inscription should be interpreted within this context, and the term daivas should probably be interpreted as a reference to the rebellious nations, and not as an indication of "demons."

Belief in a personified evil power only developed from the second century BCE onward. Chad Pierce indicates that among many factors contributing to this development, two stood out:

First, the development of a celestial enemy was heavily influenced by the Jews' experience under Babylonian and Persian rule. Exposure to Zoroastrianism [which developed from earlier Ahuaramazda worship - LCJ $]^{16}$ with its emphasis on cosmic dualism played a fundamental role in the expansion of the good versus evil dichotomy found in early Judaism. Similar to the rival gods in Persian literature, Jewish tradition never gives Satan equal status with God. YHWH alone is God, with no evil equivalent. The dichotomy of good and evil found its personified counterpart in unequal leaders in the respective figures of God and Satan. Accordingly, the idea in the Hebrew Bible of a sovereign God responsible for all things, both good and evil, was replaced with a celestial conflict between God and Satan as the leaders of two distinct warring camps. Thus, Satan may have partly evolved from those attributes earlier assigned to God that appeared questionable to both Jews and Christians in the Second Temple period.

Second, the concept of Satan as a personification of evil solidified with the rise of brutal enemies who oppressed Israel. Israel's battles against foreign enemies (especially Antiochus IV) eventually became cosmically represented in a heavenly war between God and his angels against Satan and his minions. Thus, the clash between Israel's theology of election and the reality of its foreign

Extraction \& Control: Studies in Honor of Matthew W. Stolper, ed. Michael Kozuh et al., SAOC 68 (Chicago: Oriental Institute of the University of Chicago, 2014), 166. See also her earlier essay: Amélie Kuhrt and Susan Sherwin-White, "Xerxes' Destruction of Babylonian Temples," in Achaemenid History 2, ed. Heleen SancisiWeerdenburg and Amélie Kuhrt (Leiden: Nederlands Instituut voor het Nabije Oosten, 1987), 67-78.

15 See Waters, Ancient Persia, chap. 7., who calls Xerxes "the Expander of the Realm.”

16 Some scholars indicate that in Persian Avestan Zoroastrianism the evil god, Angra Mainyu (also referred to as Ahriman), opposes the good god, Ahuramazda. See the discussion in Duane F. Watson, "Devil," $A B D$ 2:183-184. 
oppression aided in the development of Satan as an autonomous figure. ${ }^{17}$

This development found expression particularly in the so-called "intertestamental" literature, where different names (such as Belial and Mastema, apart from Satan) were used to refer to the personification of evil alongside

17 Pierce, "Satan," 1198. See also Cilliers Breytenbach and Peggy L. Day, "Satan," $D D D$ : 726-732. Formerly scholars tried to explain this development with reference to the cultural-religious context of Israel. Paul Hanson, for example, argued that the emergence of a personified view of evil and the development of apocalyptic eschatology should rather be understood in relation to the shared Canaanite myths where the Leviathan and chaos monsters were portrayed as engaging in the primordial struggle against the ordered creation of God. He indicates: "The basic schema of apocalyptic eschatology has evolved in Israel and the whole development is perfectly comprehensible within the history of Israel's own community and cult. Hasty recourse to late Persian influence is therefore unnecessary and unjustifiable." See Paul D. Hanson, The Dawn of Apocalyptic: The Historical and Sociological Roots of Jewish Apocalyptic Eschatology, rev. ed. (Philadelphia: Fortress, 1979), 60.

James Barr was of another opinion, however. He indicated: "It is customary to connect certain phenomena of the later OT and of postbiblical Judaism with Iranian influence. The development within Jewish religion of such matters as angels, dualism, eschatology, and the resurrection of the body is commonly attributed to the impact of Iranian religion. This would not be surprising, at least in theory; for the Jews lived about two centuries under the Pax Persica, and some of their most important books were written in that time." See James Barr, "The Question of Religious Influence : The Case of Zoroastrianism, Judaism, and Christianity," JAAR 53 (1985): 201. Barr furthermore indicated that there was a reluctance in the past among scholars to investigate the Persian influence: "It therefore is striking that, on the whole, biblical and Jewish studies have remained very much aloof from the study of Iranian language, literature, and religion. For most biblical scholars, the 'Oriental background of the Old Testament' has meant the Semitic background, perhaps also the Egyptian and the Hittite, but much less the Iranian. The energetic effort invested in work on Akkadian and Ugaritic parallels stands in surprising contrast to the absence of similar attention to Persian materials. ... Much of Old Testament scholarship in the 1980s shows little greater consciousness of the Iranian sources than existed before the mid-nineteenth century. ... [C]omparatively few Old Testament scholars seriously study Iranian materials. ... I know of no fresh examination of the question of Iranian influence by any major Old Testament scholar in recent years" (Barr, "Question," 201-2). This situation no longer applies. Since the time of James Barr's writing, studies in Ancient Persian history, culture, and religion blossomed. 
God. We see this in the book 1 Enoch, but also very prominently in the Qumran literature. ${ }^{18}$

By the NT period, as we have mentioned in the introduction, Satan, or the diabolos (as he is more commonly called) is a well-established figure. ${ }^{19}$ Chad Pierce summarises the presence of Satan in the NT literature as follows:

Satan is generally characterized as the ruler of a kingdom of darkness and the adversary of God. Similar to Belial at Qumran, he controls a certain log of demons and evil spirits who afflict the world with illness (Luke 13:16) and lead humanity astray (1 Cor. 7:5). At times Satan's demons "possess" humans, causing both physical and psychological impairment (Matt. 15:22). John 13:27 notes that Satan entered (eiselthen) Judas, causing him to betray Jesus. ... Christ's ministry, which inaugurates the kingdom of God on the earth, begins the overthrow of Satan's kingdom and the victory of God's rule (Luke 10:18). Jesus' authority is reflected in his ability to cure illnesses and cast out demons (Luke 11:20; Matt. 12:28). Despite the apparent overthrow of the kingdom of darkness in the Gospels, the rest of the New Testament continues to portray Satan as God's adversary leading the righteous astray, practicing deceit, and causing illness (Rom 16:20; 1 Cor. 7:5; 2 Cor. 12:7) ${ }^{20}$

18 See Anders Hultgård, "Persian Religion," EDEJ, 1048-1050; Loren T. Stuckenbruck, "The Demonic World of the Dead Sea Scrolls," in Evil and the Devil, ed. Ida Fröhlich and Erkki Koskenniemi (London: T \& T Clark, 2013), 51-70; Jutta Leonhardt-Balzer, "Evil at Qumran," in Evil in Second Temple Judaism and Early Christianity, ed. Chris Keith and Loren T. Stuckenbruck, WUNT 2/417 (Tübingen: Mohr Siebeck, 2016), 17-33; Benjamin Wold, "Demonizing Sin? The Evil Inclination in 4QInstruction," in Evil in Second Temple Judaism and Early Christianity, ed. Chris Keith and Loren T. Stuckenbruck, WUNT 2/417 (Tübingen: Mohr Siebeck, 2016), 34-48; Matthew Goff, "Enochic Literature and the Persistence of Evil Giants and Demons, Satan and Azazel," in Das Böse, der Teufel und Dämonen: Evil, the Devil, and Demons, ed. Jan Dochhorn, Susanne Rudnig-Zelt, and Benjamin G. Wold, WUNT 2/412 (Tübingen: Mohr Siebeck, 2016), 43-58; Matthew Goff, "A Seductive Demoness at Qumran? Lilith, Female Demons and 4Q184," in Das Böse, der Teufel und Dämonen: Evil, the Devil, and Demons, ed. Jan Dochhorn, Susanne Rudnig-Zelt, and Benjamin G. Wold, WUNT 2/412 (Tübingen: Mohr Siebeck, 2016), 59-76; Miryam T. Brand, "Belial, Free Will, and Identity-Building in the Community Rule," in Das Böse, der Teufel und Dämonen: Evil, the Devil, and Demons, ed. Jan Dochhorn, Susanne Rudnig-Zelt, and Benjamin G. Wold, WUNT 2/412 (Tübingen: Mohr Siebeck, 2016), 77-91.

19 See again the various essays on evil in the NT in Fröhlich and Koskenniemi, Evil; Keith and Stuckenbruck, Evil; Dochhorn, Rudnig-Zelt, and Wold, Das Böse.

20 Pierce, "Satan," 1199. 
After this brief overview of how the externalisation of evil from God and the personification of evil in a satan figure developed in late Judaism and early Christianity in close interaction with socio-religious views and sociopolitical circumstances of the time, I would like to move on to discuss one small example from the OT which stands at the beginning of this development. Thereafter, I will draw some conclusion from this development for our discussion on social-theological diagnostics.

\section{C “SATAN STOOD UP AGAINST ISRAEL” (1 CHR 21:1)}

A text which is often seen as "proof" that the personification of evil already started developing in the time of the Chronicler, is $1 \mathrm{Chr} 21: 1$. This verse forms the introduction to the Chronicler's narrative of David's census. Although the Chronicler followed the Vorlage fairly closely in retelling this narrative, he deliberately changed the instigation for the census in 2 Sam 24:1 from "Yahweh's wrath flared up against Israel" to "Satan ${ }^{21}$ stood up against Israel." This phenomenon has drawn quite a lot of scholarly discussion. ${ }^{22}$

Various theories have been formulated by scholars to explain this change. The most obvious reason would be that the Chronicler changed his

21 The majority of English translations (and similar in the 1933 and 1983 Afrikaans translations) translate the term with the personal name "Satan." See, however, the New American Bible which has "A satan rose up against Israel," with the following footnote: "A satan: in the parallel passage of 2 Sam 24:1 the Lord's anger. The change in the term reflects the changed theological outlook of postexilic Israel, when evil could no longer be attributed directly to God. At an earlier period the Hebrew word satan ('adversary,' or, especially in a court of law, 'accuser'), when not used of men, designated an angel who accused men before God (Job 1:6-12; 2:1-7; Zech 3:1-2). Here, as in later Judaism (Wisdom 2:24) and in the New Testament, satan, or the 'devil' (from the Greek translation of the word), designates an evil spirit who tempts men to wrongdoing."

22 See, e.g. Paul Evans, "Divine Intermediaries in 1 Chronicles 21: An Overlooked Aspect of the Chronicler's Theology," Bib 85 (2004): 545-58; Ken Ristau, "Breaking down Unity: An Analysis of 1 Chronicles 21:1-22:1," JSOT 30 (2005): 201-21; Ryan E. Stokes, "The Devil Made David Do It ... or Did He? The Nature, Identity, and Literary Origins of the Satan in 1 Chronicles 21:1," JBL 128 (2009): 91-106; Louis C. Jonker, "Of Jebus, Jerusalem, and Benjamin: The Chronicler's Sondergut in 1 Chronicles 21 against the Background of the Late Persian Era in Yehud," in Chronicling the Chronicler: The Book of Chronicles and Early Second Temple Historiography, ed. Paul Evans and Tyler Williams (Winona Lake, IN: Eisenbrauns, 2013), 81-102; Paul Evans, "Let the Crime Fit the Punishment: The Chronicler's Explication of David's 'Sin' in 1 Chronicles 21," in Chronicling the Chronicler: The Book of Chronicles and Early Second Temple Historiography, ed. Paul Evans and Tyler Williams (Winona Lake, IN: Eisenbrauns, 2013), 65-80; Jonker, Defining All-Israel, 122-27. 
Vorlage to resolve the theological dilemma present in 2 Sam 24 where Yahweh orders the census, but later on punishes David for performing this task. ${ }^{23}$ This surely explains logically why the subject of the initial order was changed by the Chronicler. However, this explanation does not explain why the term "satan" was chosen to resolve the matter.

The word "satan" is used as noun in two other texts in the HB, Job 2:3 and Zech 3:1, where it has the semantic potential of "the adversary/enemy." In both these cases the word is used with the determinative. While the instance in $1 \mathrm{Chr} 21: 1$ is used without determinative, some scholars argue that it should be taken as proper noun there, that is "Satan." 24 If that is indeed the case, then it would mean that $1 \mathrm{Chr} 21: 1$ contains the first and only occurrence in the HB where Satan is personified. However, the form without the determinative is not necessarily indicating a proper name, but it could also be understood as an indeterminate noun ("an adversary/enemy"). ${ }^{25}$ John Day is of the opinion that this adversary is a heavenly being, while Sara Japhet and Steven McKenzie interpret the term as reference to a worldly enemy. McKenzie's explanation makes the issue clear:

David's actions in this verse are entirely within the human context; there is no reference to the divine realm. Moreover, taking śat $t a \bar{a} n$ as a common noun - a human enemy - makes perfect sense in the verse and actually helps to make David's subsequent actions more understandable. An enemy or adversary of David's - an unnamed military foe - arose, and this in turn motivated him to take a census

23 Knoppers indicates: "A more convincing explanation for the switch in subjects emerges after one considers the challenge that the Samuel narrative posed for the Chronicler's ideology ... For the Chronicler, musters are an appropriate feature of national administration ... Moreover, the Chronicler was a firm believer in the principle of proportionality in divine-human relations ... Given these facts, the author risked presenting his audience with an untenable scenario. If he did not alter his Vorlage, Yhwh would be prompting David to do something good and then punishing him for doing it." See Gary N. Knoppers, I Chronicles 10-29: A New Translation with Introduction and Commentary, 1st ed. (New York: Doubleday, 2004), 751. See also Steven L. McKenzie, 1 \& 2 Chronicles, AOTC (Nashville: Abingdon, 2004), 170; Pieter B. Dirksen, 1 Chronicles (Leuven: Peeters, 2005), 257.

24 See, e.g., Peggy L. Day, An Adversary in Heaven: Śātān in the Hebrew Bible (Atlanta: Scholars Press, 1988); Hugh G. M. Williamson, 1 and 2 Chronicles (Grand Rapids: Eerdmans, 1982), 143-44; Sarah Japhet, I \& II Chronicles: A Commentary (Louisville: Westminster John Knox Press, 1993), 374-75; Breytenbach and Day, "Satan"; Dirksen, 1 Chronicles, 257; Ralph W. Klein, 1 Chronicles: A Commentary (Minneapolis: Fortress Press, 2006), 418-19.

25 Day, Adversary in Heaven; Japhet, I \& II Chronicles, 374-75; McKenzie, 1 \& 2 Chronicles, 170-71. 
of the fighting men under his command (v. 5). Taking a census of men of fighting age was a typical step in preparing for war in the ancient world. If this interpretation is correct, the net theological result of the Chronicler's reading is that David is personally and exclusively culpable for the offense of the census. ${ }^{26}$

In order to come to a decision it should be asked how plausible each of the three theories (Satan as proper name; satan as heavenly adversary; satan as wordly adversary) would have been in the Achaemenid context within which Chronicles originated. It is important to acknowledge that the reason for the change in the text should be sought in the Chronicler's context, and not in the narrative context of the Chronicler's David census narrative. It seems that Japhet and McKenzie did not take this point sufficiently into account in their view that "satan" is an earthly adversary, in all probability according to them, military enemies. This would make sense in the context of the narrative world, namely David's census account as constructed by the narrator. But, it is unlikely that such an understanding of "satan" would have made sense in the Chronicler's own context. This was the time of increased Persian military presence in the Levant, with Yehud and Idumea also engaged in imperial military actions. If "satan" would refer to a military adversary or enemy in the Chronicler's account, it would involve the risk of being construed as subtle criticism against the Persian military presence in their environment, or even as instigating protest against the imperial overlord. It remains questionable whether the Chronicler would have taken the risk of being seen as rebellious in his community's relationship with the Achaemenid power.

While the book Chronicles is generally dated in the late Achaemenid period (i.e., approximately in the middle of the fourth century BCE) one can still not reckon with Zoroastrianism's influence of a dualistic view of good and evil (as explained above in section B). It is therefore also highly unlikely that the mention of "satan" $1 \mathrm{Chr} 21: 1$ can be understood as fully personified evil figure. However, one may speculate whether the two religious developments mentioned in section B above could perhaps have formed the backdrop for the Chronicler's choice of "satan" instead of Yahweh in $1 \mathrm{Chr} 21: 1$. Firstly, analogous to the Daiva inscription of Xerxes (where the term daiva most likely referred to those rebelling against the king, and not to demons), the Chronicler probably wanted to indicate that the census was

26 McKenzie, 1 \& 2 Chronicles, 171. Knoppers, I Chronicles 10-29, 751, also interprets the term as "an adversary," but does not specify whether it is a wordly or heavenly enemy. He qualifies, however, that "[t]he use of śătān instead of Yhwh cannot be convincingly attributed to a shift in metaphysics from the preexilic to the postexilic age, because Chronicles nowhere else evinces an inherently dualistic view of reality. The Chronicler is as much of a monist as the Deuteronomists are ..." 
rebellion against Yahweh. The Chronicler used a term already known in his context, namely "satan," to express this sentiment in the narrative. Secondly, with the elevation of Mithra and Anahita in Persian religion during the time of Artaxerxes II in order to externalise certain functions of Ahuramazda, the Chronicler probably followed suit of this development by externalising some function of Yahweh in similar fashion. "Satan" receives the function of instigating a rebellious act so that this role is no longer performed by Yahweh directly, but rather through a heavenly intermediary.

Although from a totally different angle, Paul Evans also comes to the same conclusion:

Although Ch did not see God as altogether separate from evil he, being a product of his postexilic age, saw a more developed role for divine intermediaries. As mentioned above, this could have been the result of Ch's exposure to the book of Job where שט was part of the heavenly entourage and was used by Yahweh to test human beings. Thus, Ch believed that in his Vorlage when God incited David to number the people, this was done through a mediator - שטן. In this way, Ch was not intending to contradict his Vorlage but to better explain it. This reinterpretation by $\mathrm{Ch}$ is consistent with subsequent development of angelology in later intertestamental literature. These later books which retold OT narratives, (e.g., Jubilees) tended to bring in angels where there were none in the original OT text. Often the writer would introduce intermediaries to perform an act which God himself performs in the original story. In a similar manner, Ch replaces the original narrative's account of God directly inciting David with a heavenly intermediary - שט . $^{27}$

One could see in the Chronicler's change an attempt to adapt the census narrative towards Persian religious views. Rhetorically, this would have shown some analogies between the religion practiced in Yehud and the Persian imperial religion. Paul Evans cautions, however, that we may never be absolutely certain whether the Persian imperial context influenced this specific instance of the Chronicler's change to his Vorlage. Our views remain speculative. We agree with Evans when he indicates:

As we have seen, Ch's belief in increased roles for intermediaries is evident in his angelological reworking of 2 Samuel 24. Unlike in Ch's Vorlage, the angel is clearly distinguished from Yahweh himself. ... While Persian Dualism may have influenced this development of the increased role of intermediaries, there is no evidence that $\mathrm{Ch}$ felt the need to remove all aspects of evil from originating

27 Knoppers, I Chronicles 10-29, 554-55. 
in God. Of course, despite the distinction between the OT concept of Satan and that of later intertestamental literature (and the NT), שט in Chronicles is still a malevolent figure. This is similar to Job where שטן maligns Job's character to God in an effort to compel him to curse his maker. ... Although not representing a complete doctrine of Satan, as developed in later Jewish writings, Ch's reworking of 2 Samuel 24 was an important stage in its development. It is, in fact, the final stage in the development of שטן in the OT. Drawing on the traditions of Job and Zechariah Ch takes the concept one step further. In Chronicles שטן not only brings charges against Yahweh's people but incites his anointed king to bring "guilt upon Israel." Despite this development, the term is still a long way from denoting the archenemy of God. Instead, his appearance in Chronicles is evidence of Ch's post-exilic theology which saw increased roles for divine intermediaries. While not being the mainstay of his purpose, this belief in divine mediation is evident in his work and has been overlooked by recent commentators. $^{28}$

This example from the HB showed that there was a close connection between the religious understanding reflected in the use of the term "satan" in $1 \mathrm{Chr} 21: 1$ and the socio-political and socio-religions conditions of the Chronicler's time. This case study cautioned us not to over-interpret the influence of the Persian imperial context. But, it also cautioned us not to read back into texts from the Achaemenid era understandings which actually date from a much later period. This point will now form the focus of my subsequent engagement with attempts in Christian theology towards socialtheological diagnostics.

28 Knoppers, I Chronicles 10-29, 556-57. Ryan Stokes sees the Balaam narrative in Num. 22 as the primary influence for the change in the Chronicler's narrative. However, his conclusion is very similar to Evans's: "The preceding analysis leads one to conclude that the śat $\bar{a} n$ of $1 \mathrm{Chr} 21: 1$ came to be there by the hand of a redactor who was reading 2 Samuel 24 through the lens of the Balaam story in Numbers 22. This śătann is not merely a human opponent of Israel but a superhuman, angelic figure. Though it is not absolutely impossible that שטן in this passage is a proper noun, there is little to suggest this. The opponent here is more likely an anonymous superhuman adversary. Whether Satan or a śattān, this superhuman figure is not the archenemy of God or a tempter, as is the devil in later tradition. The śattān of $1 \mathrm{Chr}$ $21: 1$ is an emissary of the deity, carrying out YHWH's punishment of Israel" (Stokes, "Devil," 106). 


\section{IMPLICATIONS FOR A DISCUSSION ON SOCIAL- THEOLOGICAL DIAGNOSTICS}

I see in the development outlined and illustrated above, from vague forms of dualism in late Persian period Judaism (such as in $1 \mathrm{Chr}$. 21:1) to fully-blown demonology in early Christian theology (such as in the NT), the emergence of a social-theological diagnostic strategy which had clear religious-theological and political overtones. It seems that in this gradual religious-historical development a narrative emerged through which religious agents of the past and over several centuries articulated their response to the question "Where did it all go wrong?" We have seen in the description above that this mythical response carried the stigmata of its religious-historical and political environment. Or, to put it in other words: the emergence of the understanding of evil as a force outside Yahweh/God in the Judaeo-Christian tradition and the accompanying development of a personified Satan figure, were the products of religious-historical and political circumstances, but simultaneously became the explanatory models used in social-theological diagnostics of those same circumstances.

It is thus important to point out the dynamic and reciprocal relationship in this development: In their observation of, and in response to, the religious and political conditions of their day, the religious agents of old started revising their theological understandings handed down to them by tradition. However, these revised theological understandings then also started functioning as the lenses through which they viewed the religious and political developments of their own day.

This reciprocal relationship between social-historical environment and social-theological diagnostics points to an important implication. It implies that, if one wants to contribute to the discussion on social-theological diagnostics as witnessed in the Christian systematic tradition, one should be thoroughly aware of the fact that the interpretative (or, dogmatic) frameworks of this tradition are not only lenses through which reality can be observed and diagnosed. They are also inherently the products of interaction with historical reality. The reciprocal relationship between those theological models and the socio-historical circumstances within which they were first formulated, should not be ignored or underestimated.

Furthermore, it should be noted (and acknowledged) that early Christian models of social-theological diagnostics (making use of the categories of "evil," "sin," "the fall," etc.) were the products of long religioustheological developments which culminated in a world dominated by the Greco-Roman world view. This fact implies that the narratives utilised in Christian theology's participation in the discussion on social-theological diagnostics should of necessity take into account the pre-Christian trajectories that fed into the Christian models of understanding. A great part of the HB (or, 
Christian OT) does not know a dualistic explanation of evil, and certainly did not suggest that "sin" started with "the fall" (Gen 3). It might be worthwhile specifically for the Christian social-theological endeavour - to take seriously the precursors to the Greco-Roman understandings that underlie Christian doctrine, and not to regard those doctrines that were formulated under the influence of Greco-Roman culture as ontological descriptions that form absolute starting points for social-theological diagnostics in modern-day contexts.

\section{E CONCLUSION}

As indicated in an earlier footnote in this essay, my contribution wanted to celebrate the life and work of our colleague Sakkie Spangenberg by focusing on the interaction between social-religious developments in the pre-Christian era and the formation of Christian doctrine - particularly on the theme of belief in a so-called satan figure. I came to the conclusion above - with Spangenberg and others - that a long religious-historical development stands behind the belief in a satan figure. I indicated that $1 \mathrm{Chr} 21: 1 \mathrm{might}$ be the only instance in the HB where one may already observe the personalisation of evil - albeit then in a very vague form. This text from the late Achaemenid period stands at the beginning of a development that was later influenced by dualistic thinking in Zoroastrianism, and particularly by the worldview of the Greco-Roman world within which the NT originated. In the last main section I expressed the plea that Christian systematic theology should make more effort to include pre-Christian religious-historical developments - such as witnessed in the HB/OT - in their reflection and implementation of Christian doctrine. In this plea I follow the example of our dear colleague, Sakkie Spangenberg.

\section{BIBLIOGRAPHY}

Barr, James. "The Question of Religious Influence : The Case of Zoroastrianism, Judaism, and Christianity." JAAR 53/2 (1985): 201-35.

Brand, Miryam T. "Belial, Free Will, and Identity-Building in the Community Rule." Pages 77-91 in Das Böse, der Teufel und Dämonen: Evil, the Devil, and Demons. Edited by Jan Dochhorn, Susanne Rudnig-Zelt, and Benjamin G. Wold. WUNT 2/412. Tübingen: Mohr Siebeck, 2016.

Breytenbach, Cilliers and Peggy L. Day. "Satan." Pages 726-732 in Dictionary of Deities and Demons in the Bible. Edited by Karel Van der Toorn, Bob Becking and Pieter W. Van der Horst. Leiden: Brill, 1999.

Brosius, Maria. The Persians: An Introduction. PAW. London: Routledge, 2006.

Brown, Derek R. The God of This Age: Satan in the Churches and Letters of the Apostle Paul. Tübingen: Mohr Siebeck, 2015.

Burke, Jonathan. "Satan and Demons in the Apostolic Fathers : A Minority Report." SEA 81 (2016): 127-68.

Conradie, Ernst M. "The Malaise of the Human Condition: Social Diagnostics, Human Evolution, and Theological Discourse on the Contingency of Sin." 
364 Jonker, “Satan Made Him Do It!” OTE 30/2 (2017): 348-366

stias: Stellenbosch Institute for Advanced Study. http://stias.ac.za /research/projects/the-malaise-of-the-human-condition-social-diagnosticshuman-evolution-and-theological-discourse-on-the-contingency-of-sin/.

Day, Peggy L. An Adversary in Heaven: Sátān in the Hebrew Bible. Atlanta: Scholars Press, 1988.

Dirksen, Pieter B. 1 Chronicles. Leuven: Peeters, 2005.

Dochhorn, Jan, Susanne Rudnig-Zelt, and Benjamin G. Wold, eds. Das Böse, der Teufel und Dämonen: Evil, the Devil, and Demons. WUNT 2/412. Tübingen: Mohr Siebeck, 2016.

Evans, Paul. "Divine Intermediaries in 1 Chronicles 21: An Overlooked Aspect of the Chronicler's Theology." Bib 85/4 (2004): 545-58. . "Let the Crime Fit the Punishment: The Chronicler's Explication of David's 'Sin' in 1 Chronicles 21." Pages 65-80 in Chronicling the Chronicler: The Book of Chronicles and Early Second Temple Historiography. Edited by Paul Evans and Tyler Williams. Winona Lake, IN: Eisenbrauns, 2013.

Fröhlich, Ida and Erkki Koskenniemi, eds. Evil and the Devil. London: T \& T Clark, 2013.

Fuhrmann, Sebastian. "The Devil as (Convicted) Prosecutor: Some Ideas on the Devil in 1 Peter and Hebrews." IDS 50/2 (2016): 1-4.

Goff, Matthew. "A Seductive Demoness at Qumran? Lilith, Female Demons and 4Q184." Pages 59-76 in Das Böse, der Teufel und Dämonen: Evil, the Devil, and Demons. Edited by Jan Dochhorn, Susanne Rudnig-Zelt, and Benjamin G. Wold. WUNT 2/412. Tübingen: Mohr Siebeck, 2016.

. "Enochic Literature and the Persistence of Evil Giants and Demons, Satan and Azazel." Pages 43-58 in Das Böse, der Teufel und Dämonen: Evil, the Devil, and Demons. Edited by Jan Dochhorn, Susanne Rudnig-Zelt, and Benjamin G. Wold. WUNT 2/412. Tübingen: Mohr Siebeck, 2016.

Gruen, Erich S. "Persia through the Jewish Looking-Glass." Pages 53-75 in Jewish Perspectives on Hellenistic Rulers. Edited by Tessa Rajak, Sarah Pearce, James Aitken, and Jennifer Dines. Berkeley: University of California Press, 2007.

Hanson, Paul D. The Dawn of Apocalyptic: The Historical and Sociological Roots of Jewish Apocalyptic Eschatology. Rev. ed. Philadelphia: Fortress, 1979.

Herrenschmidt, Clarisse and Jean Kellens. "Daiva." EIr 6/6 (1993): 599-602. http://www.iranicaonline.org/articles/daiva-old-iranian-noun.

Hultgård, Anders. "Persian Religion." Pages 1048-1050 in The Eerdmans

Dictionary of Early Judaism. Edited by John J. Collins and Daniel C. Harlow. Grand Rapids: Eerdmans, 2010.

Japhet, Sarah. I \& II Chronicles: A Commentary. Louisville: Westminster John Knox Press, 1993.

Jonker, Louis C. "Of Jebus, Jerusalem, and Benjamin: The Chronicler's Sondergut in 1 Chronicles 21 against the Background of the Late Persian Era in Yehud." Pages 81-102 in Chronicling the Chronicler: The Book of Chronicles and Early Second Temple Historiography. Edited by Paul Evans and Tyler Williams. Winona Lake, IN: Eisenbrauns, 2013.

. "Manasseh in Paradise, or Not? The Influence of ANE Palace Garden Imagery in LXX 2 Chronicles 33:20." Pages 339-58 in Thinking of Water in 
the Early Second Temple Period. Edited by Christoph Levin and Ehud Ben Zvi. BZAW 461. Berlin: De Gruyter, 2014. . Defining All-Israel in Chronicles: Multi-Levelled Identity Negotiation in Late Persian Period Yehud. FAT I/106. Tübingen: Mohr Siebeck, 2016.

Keith, Chris and Loren T. Stuckenbruck, eds. Evil in Second Temple Judaism and Early Christianity. WUNT 2/417. Tübingen: Mohr Siebeck, 2016.

Klein, Ralph W. 1 Chronicles: A Commentary. Minneapolis: Fortress Press, 2006.

Knoppers, Gary N. I Chronicles 10-29: A New Translation with Introduction and Commentary. 1st ed. New York: Doubleday, 2004.

Kuhrt, Amélie. "Reassessing the Reign of Xerxes in the Light of New Evidence." Pages 163-69 in Extraction \& Control: Studies in Honor of Matthew W. Stolper. Edited by Michael Kozuh, Wouter F. M. Henkelman, Charles. E. Jones, and Christopher Woods. SAOC 68. Chicago: Oriental Institute of the University of Chicago, 2014.

Kuhrt, Amélie and Susan Sherwin-White. “'Xerxes' Destruction of Babylonian Temples." Pages 67-78 in Achaemenid History 2. Edited by Heleen SancisiWeerdenburg and Amélie Kuhrt. Leiden: Nederlands Instituut voor het Nabije Oosten, 1987.

Leonhardt-Balzer, Jutta. "Evil at Qumran." Pages 17-33 in Evil in Second Temple Judaism and Early Christianity. Edited by Chris Keith and Loren T. Stuckenbruck. WUNT 2/417. Tübingen: Mohr Siebeck, 2016.

McKenzie, Steven L. 1 \& 2 Chronicles. AOTC. Nashville: Abingdon, 2004.

Pagels, Elaine. The Origin of Satan: How Christians Demonized Jews, Pagans, and Heretics. London: Penguin Vintage, 2011.

Pierce, Chad T. "Satan and Related Figures." Pages 1196-1200 in The Eerdmans Dictionary of Early Judaism. Edited by John J. Collins and Daniel C. Harlow. Grand Rapids: Eerdmans, 2010.

Ristau, Ken. "Breaking down Unity: An Analysis of 1 Chronicles 21:1-22:1." JSOT 30/2 (2005): 201-21.

Rudnig-Zelt, Susanne. "Der Teufel und der alttestamentliche Monotheismus." Pages 1-20 in Das Böse, der Teufel und Dämonen: Evil, the Devil, and Demons. Edited by Jan Dochhorn, Susanne Rudnig-Zelt, and Benjamin G. Wold. WUNT 2/412. Tübingen: Mohr Siebeck, 2016.

Schmitt, Rüdiger. The Old Persian Inscriptions of Naqsh-I Rustam and Persepolis. CII 1/2. London: School of Oriental and African Studies, 2000.

Spangenberg, Izak J. J. "A Brief History of Belief in the Devil (950 BCE - 70 CE)." SHE 39 Supplement (2013): 213-45.

Stokes, Ryan E. "The Devil Made David Do It ... or Did He? The Nature, Identity, and Literary Origins of the Satan in 1 Chronicles 21:1." JBL 128/1 (2009): 91-106.

Stuckenbruck, Loren T. "The Demonic World of the Dead Sea Scrolls." Pages 51-70 in Evil and the Devil. Edited by Ida Fröhlich and Erkki Koskenniemi. London: T \& T Clark, 2013.

Szreter, Adam. "Cronje names devil who made him do it." The Guardian, 2 June 2000. Online: https://www.theguardian.com/sport/2000/jun/02/cricket.

Waters, Matt W. Ancient Persia: A Concise History of the Achaemenid Empire, 550330 BCE. Cambridge: Cambridge University Press, 2014. 
366 Jonker, “Satan Made Him Do It!” OTE 30/2 (2017): 348-366

Watson, Duane F. "Devil." Pages 183-184 in vol 2 of The Anchor Bible Dictionary. Edited by D. Noel Freedman. New York: Doubleday, 1992.

Williamson, Hugh G. M. 1 and 2 Chronicles. Grand Rapids: Eerdmans, 1982. Wold, Benjamin. "Demonizing Sin? The Evil Inclination in 4QInstruction." Pages 34-48 in Evil in Second Temple Judaism and Early Christianity. Edited by Chris Keith and Loren T. Stuckenbruck. WUNT 2/417. Tübingen: Mohr Siebeck, 2016.

Prof. Louis Jonker, Department of Old and New Testament, University of Stellenbosch.Email: LCJ@sun.ac.za. 